\title{
A Study of Mutual Fund Flow and Market Return Volatility
}

\author{
Eric C. Chang \\ School of Business \\ The University of Hong Kong \\ Pokfulam Road, Hong Kong \\ Tel: (852) 2857-8347 \\ Fax: (852) 2858-5614 \\ Email: ecchang@business.hku.hk \\ and \\ Ying WANG \\ School of Business \\ The University of Hong Kong \\ Pokfulam Road, Hong Kong \\ Tel: (852) 2249-0615 \\ Fax: (852) 2858-5614 \\ Email: wypony@business.hku.hk
}

\author{
This Draft: May 17, 2002 \\ Very Preliminary \\ For Conference Submission
}




\title{
A Study of Mutual Fund Flow and Market Return Volatility
}

\begin{abstract}
In this study, we investigate the impact of institutional trading on the market by examining the daily relation between aggregate flow into U.S. equity funds and market volatility. We differentiate the impact of fund inflow and outflow, respectively, on the market volatility. Our empirical results show that there exists an asymmetric concurrent relationship between fund flow and market volatility: fund inflow is negatively correlated with market volatility while fund outflow is positively correlated with market volatility. We also discuss the potential explanations for our results and suggest that our results are consistent with information content differences of funds' buys and sales.
\end{abstract}




\section{Introduction}

Stock market volatility has received great attention from investors, regulators, press and academicians and is especially closely watched by many option traders since the option value is largely dependent on the volatility of its underlying asset. Existing literature documents evidence that volatility is time-varying and calls for a better understanding why volatility has changed over time. For example, based on monthly observations, Schwert (1989) reports that stock volatility exhibits substantial changes from 1857 to 1987. Haugen, Talmor, and Torous (1991) document a large variation in volatility over the period 1897 through 1988 by using daily return data. Lockwood and Linn (1990) examine the intraday market returns during 1964-1989 and show that volatility is higher for intraday than overnight periods.

The popular press often quotes the view of practitioners to suggest that greater institutional participation may account for the volatility variation. Sias (1996), for example, quotes "Reviewing this week's events, analysts are concluding that professional investors simply overreacted..." (Wall Street Journal (WSJ), July 21, 1995, p. A1). The quote highlights that institutional traders have been perceived as a contributor to the stock market volatility. This view is echoed by another quote: "Small investors, through their purchase of stock mutual funds, have emerged as the major driving force that has propelled the Dow Jones Industrial Average." (WSJ, February 26, 1993, p. C1).

Notwithstanding these perceptions and fears, we know little empirically about the relationship between market volatility and institutional traders, especially the mutual fund traders. Recently, considerable academic attention has been given to the price impact of mutual fund trading. While many prior studies have documented the price effect of money inflow into a mutual fund on individual mutual funds (Chan and Lakonishok, 1993, 1995, 1997; Keim and Madhavan, 1997; Jones and Lipson, 1999), some other literatures study the relation between the aggregate cash flow into all mutual funds and market-wide returns. In general, these studies focus on the following questions: Does mutual fund flow respond to either contemporaneous or lagged security returns? Do security returns respond to contemporaneous or lagged mutual flow, and, if they do, is there a price pressure, an information effect, or a 
positive feedback effect in which a shock to security returns can affect flow, which then affects returns, and so on?

Warther $(1995,1998)$ finds a very strong contemporaneous relation between unexpected flow and stock returns at monthly frequency. But he also argues that this relationship is not sufficient to infer causality between flow and returns because return could drive flow, or flow could drive return, or a third factor, such as new information, could drive both. Although he cannot distinguish the causality between them, he suggests a plausible causal link from flow to returns. He also investigates the lead-lag relation between flow and returns, but he rejects both sides of feedback trading, arguing that security returns neither lag nor lead mutual fund flow. Edelen and Warner (2001) further address this issue using higher-frequency data. They report that aggregate unexpected mutual fund flow is positively correlated with concurrent market returns at daily frequency. They also find the causality from flow to returns within the day and the one-day lagged response of aggregate flow to market returns. However, they argue that, unlike Warther (1995), who finds a very high correlation $\left(\mathrm{R}^{2}=55 \%\right)$ between monthly flow and returns, they document that variation in aggregate flow only accounts for $3 \%$ of the variation of daily market index returns, thus providing limited evidence on the common public view that mutual fund flow would cause the movement of security prices.

Taken together, the empirical evidence in general suggests that mutual fund flow will affect market returns. But an interesting question remains: would flow affect market volatility? If so, what is the direction of the relationship between mutual fund flow and volatility?

In recent years, considerable studies have looked at the impact of institutional trading on the volatility of stock prices, yet whether it would increase or reduce market volatility is still a controversial issue. The empirical evidence on this issue is rather conflicting. Some studies suggest a negative contemporaneous relation between volatility and institutional trading. For example, Reilly (1979) claims that institutional trading actually reduces stock price volatility rather than promoting it. Badrinath, Gay, and Kale (1989) and Arbel, Carvell and Strebel (1983) also suggest reduced volatility is associated with increased institutional trading. However, many other researches indicate the other way around. For example, Sias (1996) documents the positive contemporaneous relation between change of institutional ownership and volatility. 
$\mathrm{Xu}$ and Malkiel (2002) point out that most of increased idiosyncratic volatility is attributable to the institutional ownership.

An argument along similar lines, but that assigns somewhat more direct responsibility to institutional trading, concerns the role of mutual funds in the stock market volatility. As far as we know, there is little analysis that explicitly examines the relation between the aggregate mutual fund flow and market volatility. Warther (1998) does ask the similar question whether increased mutual fund flow will lead to increased market instability, but he provides no empirical evidence that directly address the flow-volatility relation. And it seems that the question can not be simply answered in affirmative without further tests because a reliably positive, simple relation between conditional market returns and conditional market volatility has not be found in empirical studies (See, e.g., French, Schwert and Stambaugh, 1987; Campell, 1987; Glosten, Jagannathan, and Runkle, 1993; and Whitelaw, 1994). This is also pointed out by Busse (1999), when he is investigating the market volatility timing instead of return timing. Thus, in this study, we will examine the relation between mutual fund flow and the stock market volatility, thus providing additional evidence on the impact of institutional trading on stock market volatility from a new perspective.

We find a negative contemporaneous volatility-flow relation when we examine aggregate net mutual fund flow across the whole flow range. This implies that increases in flow are associated with less volatile market.

However, a more careful examination suggests that this might not be the case since the above investigation fails to differentiate between inflow and outflow. Will negative relation still holds for inflow and outflow respectively? The answer is not clear without further tests. Karpoff (1987) discusses the asymmetric concurrent relation between volume and price changes in financial markets depending on the direction of price changes: when prices go up, volume increases; but when prices go down, volume also increases. However, previous studies that do not consider the asymmetry Karpoff discusses usually document a positive contemporaneous relation between volume and price changes. Karpoff argues that tests of the volume-price changes relation that do not differentiate positive and negative price changes are misspecified because they are based on the implicit false assumption that the relation between volume and price changes is monotonic. Hence we would take into account the direction of flow in case a similar misspecification problem occurs in our studies. 
An interesting finding emerges after we take into account the direction of aggregate net flow: there is a marked asymmetry between the impact of inflow and outflow on the market. We document that the fund inflow is negatively correlated with market volatility while the fund outflow is positively correlated with market volatility. This confirms our prior conjecture: it is necessary to distinguish between inflow and outflow; otherwise, we would infer false concurrent volatility-flow relation from previous models.

Our results are consistent with the hypothesis that both individual investors and trading strategies of mutual fund managers are influential on the market. On the one hand, individual investors use mutual funds shares as liquidity tools by buying (redeeming) fund shares during up (down) market periods. On the other hand, the trading strategies (e.g. herding) of mutual fund money managers will have an impact on the market; their behavior does not necessarily stabilize or destabilize the market depending on whether their trading or herding contains information about fundamentals. Our studies suggest the joint roles played by individual investors and fund managers in the market.

Moreover, our findings are also consistent with the information effect proposed in price impact asymmetry literatures (see, e.g., Chan and Lakonishok, 1993, 1995; Saar, 2001). That is, there are differences of information content in mutual funds' buying and selling behaviors: buys tend to convey more information than sales. We propose at least one potential explanation for the asymmetric concurrent volatility-flow relations. Mutual funds devote substantial resources to gather, analyze information and make decisions based on their private information. However, when market is down, individual investors tend to redeem fund shares on a daily basis. Thus, mutual fund managers are forced to sell stocks from their portfolios to satisfy this liquidity more often than are forced to buy stocks. Moreover, it is also possible that fund managers tend to over-react to market information or sell stocks in a panic when market is down. In general, they argue that the trading of mutual fund managers on selling stocks contains less information than their trading on buying stocks. If this is the case, we will expect negative relation between volatility and inflow and positive relation between volatility and outflow (ignore the sign). That is just what we find in our studies.

The remainder of the paper is organized as follows. Section 2 reviews the stabilization and destabilization argument about the impact of the institutional trading 
on the stock market. Section 3 discusses the flow data and the volatility measures. Section 4 presents the paper's main results using daily data. Section 5 discusses the potential explanations for the asymmetric relationship. The paper concludes with Section 6.

\section{Argument: stabilizing or destabilizing?}

Whether the institutional trading stabilizes or destabilizes the market is a controversial issue that long interests the researchers and practitioners. The most commonly cited ways in which institutions stabilize or destabilize stock prices include herding and positive-feedback trading, noisy trading and investors' preference. In this section, we would review the stabilizing and destabilizing argument about the impact of institutional trading on the market.

\subsection{Herding and positive-feedback trading}

Lakonishok, Shleifer, and Vishny (1992) make an excellent discussion of the impact of herding and positive-feedback trading on the stock market. They argue that institutions may destabilize stock prices and increase market volatility in two ways. First, institutional money managers tend to trade in the same direction at the same time, thereby exacerbating price movements. In other words, institutional herding, or correlated trading across institutional investors may drive prices away from fundamental values and thus increase price volatility. Second, due to agency problems, money managers might follow positive-feedback trading strategies based not on fundamental values of stocks, thus moving prices away from fundamentals and destabilizing the market. However, they also argue that herding and positive-feedback trading do not necessarily destabilize the market. Institutions might appear to herd if they all react to the same fundamental information in time or counter the same irrational moves in individual investor sentiment. If so, they are stabilizing the market by speeding up the adjustment of prices to new fundamentals. Moreover, positivefeedback trading destabilizes prices if funds buy overpriced and sell underpriced stocks, but stabilizes prices if funds do the opposite. For example, such trading could bring stock prices close to their "true values" if investors underreact to news. 
The empirical evidences on this facet are also inconsistent. On the one hand, some studies show that institutional herding may not be related to information and thus may destabilize the market prices. For example, Dreman (1979) suggest that institutional herding can result from irrational psychological factors and cause temporary price bubbles. Scharfstein and Stein (1990) suggest that agency problems can encourage institutional herding or feedback trading. By following the trading of others (i.e., buying when others are buying, and selling when others are selling) rather than responding to their private information, institutions will amplify exogenous stock price shocks. De Long, Shleifer, Summers and Waldmann (1990a) show that positivefeedback trading strategies are connected with higher volatility. In addition, the positive-feedback trading, or momentum trading, or "return chasing" has been well documented (e.g., Jegadeesh and Titman, 1993; Chan, Jegadeesh and Lakonishok, 1996). On the other hand, some other paper supports the stabilizing effect of institutional herding. Bikhchandani, Shilfer, and Welch (1992) and Hirshleifer, Subrahmanyam, and Titman (1994) show that if, for example, institutional investors are better informed than individual investors will likely appear to herd to undervalued stocks and away from overvalued stocks, thus moving prices toward, rather than away from, equilibrium values. Sias and Starks (1997) also reveal that the returns on portfolios dominated by institutional investors lead the returns on portfolios dominated by individual investors, consistent with the hypothesis that institutional trading reflects information and increases the speed of daily stock price adjustment. Nofsinger and Sias (1999) show that institutional investors, at the margin, are better informed than other investors. Wermers (1999) investigates the impact of mutual fund herding on stock prices and documents that stocks that herds buy outperform stocks that they sell. The results are consistent with theories where managers herding on new information about the fundamentals and help to speed up the information incorporation process.

\subsection{Noisy trading}

Advocates of a positive relationship between institutional trading and volatility refer to the "noise trader" theory of DeLong et al. (1990b), which shows that the unpredictability of noise traders' beliefs creates excessive risk, resulting in significant divergent of stock prices from fundamental values. DeLong et al. (1991) also present 
a model to show that noise traders are associated with excess volatility in the market. Yet, they fail to note the fact that institutional investors are more likely behave rationally (i.e., less likely to trade on "noise" or "fads") than individual investors, as indicated by Chopra, Lakonishok and Ritter (1992), Lakonishok, Shleifer and Vishney (1994) and Brennan (1995). Zweig (1973) and Brennan (1995) also argue that institutional investors are "smart money" investors, who will stabilize asset prices by offsetting the irrational trades of individual investors.

\subsection{Investors' preference}

Some studies cite the institutional traders' preference to suggest a positive contemporaneous relation between volatility and institutional trading. For example, Kothare and Laux (1995) suggest that institutional investors are associated with morevolatile stocks. However, other academic evidences indicate the other way around. For example, Badrinath, Gay, and Kale (1989) and Arbel, Carvell and Strebel (1983) suggest that institutional traders are prudent and more likely to avoid riskier (and typically smaller) stocks, and thus are associated with lower volatility. Gompers and Metrick (2001) also suggest that large institutions, as compared to other investors, prefer to invest in large, more liquid stocks.

Given these arguments, increased institutional trading is not necessarily associated with increased volatility or reduced volatility in light of the existent theories and evidences. Therefore, we must appeal to empiricism to investigate the relation between institutional trading and market volatility.

\section{Data and Measurement of volatility}

\section{1. Mutual fund flow data}

Our data on daily net mutual fund flow come from Trim Tabs (TT) financial services of Santa Rosa, California. TT has furnished us with the daily data on NAVs and total net assets (TNAs) for a sample of over 800 mutual funds. The sampling period is from February 2, 1998 to December 29, 2000. The data include equity funds and bond funds, which represent approximately $15 \%$ and $12 \%$ respectively of the total 
funds covered by Investment Company Institute (ICI). Our sample ends December 29, 2000. TT also provides us with daily net fund flow (new subscription less redemptions) based on the following formula:

$$
\text { Flow }_{t}=T N A_{t}-N A V_{t} \frac{T N A_{t-1}}{N A V_{t-1}}
$$

\subsubsection{Fund classification and aggregation}

Since we want to explore the impact of aggregate mutual fund flow on the US stock market volatility, our focus in this study is on the domestic equity mutual funds. Therefore, we isolate domestic equity funds from other funds. We then match the whole sample with those in CRSP survivor-bias free US mutual fund database and classify the funds by the investment objectives. Warther (1995) classifies mutual funds by the ICI category. Therefore, we also refer to the ICI Mutual Fund Factbook (2001, p.3-p.6) and include the funds with the following investment objectives in our sample: aggressive growth (AG), growth and income (GI), long-term growth (LG), sector funds (SF), total return (TR), utility funds (UT), income (IN) and precious metals (PM). Unlike Warther, we exclude international equities (IE) funds from our sample, given that we are concerned with the U.S. domestic equity market volatility. This is also consistent with Edelen and Warner (2001). However, it may be controversial whether or not global equity (GE) and balanced (BL) funds should be included in our sample, since GE funds invest in both US and international equities and BL funds invest in a mix of equity securities and bonds. Hence, we will perform robustness check by including GE and BL funds to see if the results are, in particular, sensitive to them. The final sample contains 411 domestic equity mutual funds.

\subsubsection{Data filter}

Before aggregating the daily U.S. equity mutual fund flow data, there are many issues that we should address. First, we need to filter NAVs and TNAs. TT advises us that their data are prone to errors such as interchanged digits and digit transposition, because the data are in hand-collected procedure. Greene and Hodges (2000), Goetzmann, Ivkovic and Rouwenhorst (hence GIR, 2000), and Chalmers, Edelen and Kadlec (hence CEK, 2000) also address this issue. Second, similar to CEK (2000), we 
would employ two filters to fill out data error in NAVs and TNAs series, and calculate the net flow on the basis of these two series.

First, we would apply a five standard-deviation filter to daily percentage change in NAVs (daily return) and TNAs. That is, we would remove observations if the absolute value of daily percentage change in NAVs or TNAs is greater than five standard deviations, where the standard deviation is calculated on a fund-by-fund basis. As noted by CEK (2000), it is a decidedly rare event in the true data since a five standard-deviation move in the value-weighted NYSE index has happened 14 times since 1965 .

A second filter, which is designed to catch false reversals, is also applied to the absolute values of daily percentage change in both NAVs and TNAs series. CEK (2000) point out that, a three standard-deviation move in the NYSE index has happened 92 times over the past 33 years, or about three times a year. However, a subsequent reversal back to within 1.5 standard deviations of the original (two days prior) value has happened only 15 times. Therefore, we would remove if the observation is a three standard deviations move followed by a reversal back to within 1.5 standard deviations of the original (two days prior) value. This filter, thus, historically removes less than $0.25 \%$ of true data. Nevertheless, removing true extreme negative autocorrelation biases the remaining data toward positive autocorrelation. To offset this, we would remove if the observation is a three standard deviation move followed by a further 1.5 standard deviation move in the same direction the next day. This happened with the NYSE index 26 times between 1965 and 1999.

CEK (2000) also argue that the filters thus constructed, suggest that no bias arises. On the one hand, they do not materially distort true autocorrelation because the autocorrelation of daily returns of the value-weighted NYSE index over the $1965-$ 1999 period is $14 \%$ without filters and $15 \%$ with filters. On the other hand, the filters almost surely remove most data errors. If a data-entry error is present, e.g. a digit transposition, then it is likely to be greater than 3 or 5 standard deviations, or about $5 \%$, in magnitude. For example, digit transpose in NAV is typically about a $10 \%$ error if it occurs in the cents' columns and far greater in the dollars column.

\subsubsection{Timeliness}


In addition to typo concerns, another potential problem is the timeliness of fund flow data. We are not the only researchers who have noted this problem. Edelen and Warner (2001) suggest that TT include the funds in their sample only if the funds can reliably provide up-to-date daily NAV. They employ various tests to reject the hypothesis that TT reports one-day old data. Although they cannot reject the partially updated data (with updated NAV but not reflecting the day's fund-share transactions) hypothesis, they also note that the test power is limited by the availability of semiannual SEC report. Further, even if a fund shows a one-day reporting lag based on the comparisons of SEC and TT data, whether there is also a one-day lag for all other days is unclear. Therefore, they caution that merely adjusting the fund's data by one day is subject to potentially severe classification errors. Thus, they don't make any adjustment to their data in the end and just argue that this only strengthens their paper's main conclusion that flow-motivated trade has an aggregate price impact. GIR (2000) employ similar methodology in Edelen and Warner (2001) to determine the reporting practice for each of the international funds in their sample. They differ from Edelen and Warner in that they check the data with that in the CRSP mutual fund database. Thus, they identify 88 out of 116 funds in their sample to be reporting the appropriate total net assets, 3 funds to be reporting one day lagged TNA, while the data for the remaining 25 funds were either too noisy to make a determination or were not available for 1998. Therefore they conclude that overwhelming majority of the funds in their sample seem to have followed the proper practice of reporting "postflow" total net assets. They also point out that the results obtained under the assumption that all 116 funds report timely data and those obtained for the 91 funds whose likely reporting practice they were able to identify are very similar, so they only report the former.

Therefore, in this research, we would, like Edelen and Warner (2001), make no adjustments to fund flow data. However, we also note that since we focus on the interaction of daily aggregate fund flow with daily volatility, we must be very careful to determine whether the fund data is timely or one day lagged. Thus we would also use the methodology in Edelen and Warner (2001) to test the timeliness of the flow data for purpose of robustness check.

\subsubsection{Distribution of dividends}


TT advises us that flow in the presence of dividends is pure guesswork because mutual funds do not handle distributions in a uniform manner. Hence, since most distributions happen in December, we would check our results by discarding December data from our sample to see whether or not a non-trivial change occurs.

\subsubsection{Properties of daily aggregate mutual fund flow}

The dollar value of TT asset base varies dramatically from 340 billion to 810 million during our three-year time period. Therefore, we will normalize flow by expressing it as a percentage of the previous day's asset base. Thus, normalized flow is defined as the one-day percentage change in TNA, less the one-day percentage change in NAV.

\section{Insert Table 1}

Summary statistics for normalized flow data are presented in Table 1. Panel A describes the characteristics of aggregate flow by investment objectives. The daily flows of aggressive growth funds, growth and income funds, long-term growth funds and sector funds are on average positive, while average flows of total return funds, utility funds, income growth funds and precious metals funds are negative. Moreover, the mean of the aggregate U.S. equity mutual fund flow is 2.94 basis points $(0.0292 \%)$. There is substantial autocorrelation of the flows for all fund groups. Especially, for aggregate flow, there is statistically significant negative autocorrelation at lags 1 and 2, but there is no significant autocorrelation at lag 5. This is also consistent with Edelen and Warner (2001). Thus, there is no obvious week effect in aggregate flow data. The time series data of daily aggregate U.S. equity funds are depicted in Figure 1.

\section{Insert Figure 1}

However, despite the average positive aggregate flow, we notice that among the 735 observations of aggregate net flow data, 416 observations are positive while 319 observations are negative. That is, during about $43 \%$ of time period, aggregate cashes flow out of rather than into the equity mutual funds. Thus, it seems important to differentiate the impact of aggregate inflow and outflow. We will address this issue in 
detail later. Here we present the summary statistics of aggregate net inflow and outflow respectively in Panel B of Table 1. From the data, we can see that aggregate net inflow is on average larger than aggregate net outflow.

\subsection{Measurement of daily volatility}

In order to examine the relation between aggregate mutual fund flow and volatility, we must, first of all, construct measures of daily market volatility. Since volatility is inherently unobservable, many estimators of time-varying market volatility have been developed in the recent financial literatures. For example, we can estimate the volatility based on the parametric econometric models such as generalized autoregressive conditional heteroskedasticity $(\mathrm{GARCH})$ or stochastic volatility models, or the implied volatility based on option prices and a pricing model such as Black-scholes, or the historical volatility based on ex post squared or absolute returns.

\subsubsection{Alternative volatility estimators}

Three measures of daily market volatility are used in this study. The first is the high-frequency volatility estimator proposed by Andersen, Bollerslev, Diebold and Labys (hence ABDL, 2001) and Andersen, Bollerslev, Diebold and Ebens(hence ABDE, 2001). They develop a daily volatility estimator by simply summing intraday squared returns. They argued that the estimators thus constructed are, in theory, free of measurement error as well as model-free. The high-frequency volatility estimator is defined as:

$$
\sigma_{H i g h, t}=\sqrt{\sum_{i=1}^{1 / \Delta}\left(\log \frac{P_{t+i \Delta}}{P_{t+(i-1) \Delta}}\right)^{2}}
$$

where $\sigma_{H i g h, t}$ denotes the daily market volatility on day $t, \Delta$ is the number of 5-minute in one trading day, and $P_{t+h}$ is the intraday 5-minute S\&P 500 index prices on day $t$. ABDL (2001) justified that a sampling frequency of 5 minutes will be appropriate, because it is high enough to mostly avoid measurement error and low enough to avoid microstructure biases. We obtain the intraday 5-minute return data on the S\&P 500 index from Tick Data, Inc, one of the first companies in the world to offer historical tick-by-tick prices on the futures and index markets. 
However, in order to prevent our inferences from being sensitive to the particular volatility estimators used, we also adopt two other estimators to check the robustness of the result.

One is the extreme value estimator developed by Parkinson (1980), which is defined as

$$
\sigma_{H L, t}=0.601 \ln \left(H_{t} / L_{t}\right)
$$

where $H_{t}$ and $L_{t}$ are respectively the highest and lowest index prices on day t. We use the daily S\&P 500 prices from Reuters Database.

Another alternative to these aforementioned estimators is the implied volatility of an option on a market index. The Chicago Board Options Exchange (CBOE) begins to quote a daily frequency implied volatility index $\left(\sigma_{V I X}\right)$ based on the option of S\&P 100 index (OEX) in 1986. Our sample begins from February 2, 1998 till December 29, 2000.

\title{
3.2.2. Properties and correlations of volatility estimators
}

\author{
Insert Table 2
}

\section{Insert Figure 2}

Summary statistics for alternative daily volatility estimators are shown in Table 2. From Panel A., we can see that all three volatility estimators show substantial positive autocorrelation. Thus, we should control for this autocorrelation in our later tests. Moreover, implied volatility $\left(\sigma_{V I X}\right)$ is on average higher than volatility estimated from high-frequency intraday data $\left(\sigma_{H i g h}\right)$ and high-low volatility $\left(\sigma_{H L}\right)$. But from the correlations shown in Panel B., we can see that these three volatility estimators are highly correlated. The time series of three volatility estimators are shown in Figure 2. To save space, we will present our results mainly by using high-frequency volatility. Also, to prevent our inferences from being sensitive to the particular estimators used, we will repeat all the analyses with the high-low volatility and implied volatility index time series. 


\section{Empirical Results}

\section{1. Daily flow-return relations}

Edelen and Warner (2001) document a daily relation between aggregate equity mutual fund flow and NYSE composite index returns during a time period from February 1998 to June 1999. Our data on flow come from the same source as theirs but differs from their data in that we do not have aggregate net flow at equity mutual funds. Instead, TT provides us with daily data of NAVs, TNAs and flow on a sample of about 800 funds. Then we aggregate the domestic equity fund flow on our own and normalize the flow by dividing it by the previous day's TNA. Thus, we will replicate their tests of flow-return relation but on a much longer time period to see the validness of our flow data. The results are shown in Table 3.

Insert Table 3

In Panel A., daily flow is regressed on lagged flow and concurrent and lagged returns. From Column 1 and Column 2, we can see that flow is highly related to lagged flow and lagged return. Especially, we use column 2 as expected flow model used in Panel B. The focus of Panel A. is the concurrent flow-return relation after controlling for lagged flow and lagged returns, which is presented in Column 3. From Column 3, the relation between concurrent returns and flow is positive, with a tstatistics of 2.01. This is consistent with the concurrent flow-return relation presented in Edelen and Warner (2001).

In Panel B., returns are regressed on concurrent and lagged flow, using both the raw series and the expected-unexpected flow series. Expected daily flow is taken from the model in Panel A., Column 2. and unexpected flow is actual minus expected. Column 4 presents the regression of returns on concurrent and lagged raw flow. Column 5 and Column 6 show the regression of returns on expected and unexpected flow. From these two columns, we can see that returns are positively related with contemporaneous unexpected flow but not related with expected flow. The results are also consistent with Edelen and Warner (2001) though our results using longer time period are a little weaker than their results. 
We also perform similar tests during two sub-time periods: during time period from Feb. 1998 to June 1999 (same time period as Edelen and Warner's paper), we get very similar results as Edelen and Warner's; during time period from July 1999 to Dec. 2000, the results are a little weaker. Although we do not report the results for the sub-time periods here to save space, we are confident that our data on flow can reflect the impact of mutual fund flow on the market.

\section{2. Regression of volatility on aggregate flow}

The main focus of our paper is to investigate the concurrent flow-volatility relation. As we discussed before, we have constructed three estimators of volatility. For brevity, we will use the high-frequency volatility estimator to present our main results and use high-low volatility and implied volatility index for purpose of robustness check. We examine the following models:

$$
\begin{aligned}
& \operatorname{Ln}\left(\sigma_{\text {High, }}\right)=\text { Flow }_{\mathrm{t}}+\operatorname{Ln}\left(\sigma_{\text {High, } t-1}\right)+\operatorname{Ln}\left(\sigma_{\text {High, } t-2}\right)+\operatorname{Ln}\left(\sigma_{\text {High, } t-3}\right) \\
& \operatorname{Ln}\left(\sigma_{\text {High, }}\right)=\text { Flow }_{\mathrm{t}}+\text { Dummy }+\operatorname{Ln}\left(\sigma_{\text {High, } t-1}\right)+\operatorname{Ln}\left(\sigma_{\text {High, } t-2}\right)+\operatorname{Ln}\left(\sigma_{\text {High, } t-3}\right) \\
& \operatorname{Ln}\left(\sigma_{\text {High, }}\right)=\text { Flow }_{t}+\text { Dummy }+\mathrm{TV}_{\mathrm{t}}+\operatorname{Ln}\left(\sigma_{\mathrm{High}, \mathrm{t}-1}\right)+\operatorname{Ln}\left(\sigma_{\mathrm{High}, \mathrm{t}-2}\right)+\operatorname{Ln}\left(\sigma_{\mathrm{High}, \mathrm{t}-3}\right)
\end{aligned}
$$

where $\sigma_{\text {High, } t}$ is the high-frequency volatility estimator on day $t$, flow ${ }_{t}$ is the aggregate net mutual fund flow on day t, dummy is defined as 1 when the market return on day $t$ is positive and 0 when the market return on day $t$ is negative, $T_{t}$ refers to the trading volume (we use turnover as a proxy) on day $\mathrm{t}$.

\section{Insert Table 4}

Table 4 presents the regressions of high-frequency volatility on flow. In Column 1, we regress the natural logarithm of daily volatility on concurrent flow after controlling for the persistence in the market volatility. That is, we take into account the natural logarithm of lagged daily volatilities in our tests to account for this persistence. If they are not included as controlling regressors, there will be a positive bias on any included regressor that covaries with lagged volatilities. Thus, the estimation process would be biased and incorrectly reflect the concurrent relation 
between volatility and flow. From Column 1, the relation between concurrent volatility and flow is significantly negative, with a t-statistic of -4.75 . This implied that increased aggregate fund flow is associated with decreased market volatility.

In Column 2, we also include a dummy variable as explanatory variable in our regression given the negative correlation between the S\&P 500's daily returns and volatility. The dummy variable is defined as 1 when the market return is positive and 0 when the market return is negative. The results indicate that adding the dummy term does not materially affect the flow coefficient. Moreover, the coefficient of dummy variable is -0.12 with a t-statistics of -6.0 . This implies that bear market is associated with higher volatility than bull market. This is also consistent with empirical results (see, e.g., Campbell, Koedijk and Kofman, 2002).

Another issue that catches our attention is the well-documented positive relation between trading volume and volatility (e.g., karpoff, 1987). As Edelen and Warner (2001) have suggested, unexpected flow should proxy for subsequent unexpected institutional trading volume. However, as Edelen (1999) has documented a positive relation between gross flow (a half of the sum of inflow and outflow) and trading volume, a positive relation between net flow (inflow minus outflow) and trading volume does not necessarily follow. Moreover, if mutual fund flow is merely a substitute for trading volume, then the flow-volatility relation thus gained would be a spurious consequence of the universal trading-volatility relation. Therefore, we include trading volume as a regressor in Column 3, to check whether the volatilityflow coefficient is still statistically significant after controlling for trading volume, thus getting more consistent and unbiased results. We use turnover rate, that is, daily trading volume divided by shares outstanding at the end of previous day, as a proxy for trading volume. The results suggest that flow is still strongly related to market volatility even after controlling for trading volume.

The evidence so far seems to suggest that there exists a negative relation between contemporaneous flow and volatility. But a more careful examination will show that this may be misspecified. We will address this issue in the next sub-section.

\section{3. Regression of volatility on aggregate net inflow and outflow}

\subsubsection{Misspecification of previous models}


In the previous part, we find negative concurrent relation between volatility and flow. In other words, it appears that the larger is the cash flow, the more volatile is the market. But this may be misspecified because we fail to differentiate between cash inflow into equity mutual funds and cash outflow from funds. To illustrate this point, we first look at the classical volume-price change relation.

\section{Insert Figure 3}

Karpoff (1987) makes an excellent review on the relation between trading volume and price changes and presents a model that suggests an asymmetric concurrent relation between volume and price changes in financial markets. He points out that, as illustrated in the $\mathrm{V}$ shape in Figure 3, there exist a positive relation between volume and positive price changes and a negative relation between volume and negative price changes. Moreover, Karpoff argues that tests on linear relation between volume and

price changes per se will yield positive correlations, as shown in the slope of the dotted line that connects the midpoints of the sides of the V shape in Figure 3. The positive concurrent relation between volume and price changes is also consistent with the findings of Morgan (1976), Rogalski (1978), Harris (1984, 1986) and Richardson, Sefcik, and Thompson (1987). However, Karpoff asserts that tests of the volume-price change relation without differentiating positive and negative price changes are misspecified. The reason is not far to see: when it is possible that the relation between volume and price changes is not monotonic, it is not correct to examine volume-price change relations across a broad price change range.

We may face a similar scenario when we investigate the volatility-flow relation given that our previous models are based on the implicit assumption that the volatility-flow relation is functional and/or monotonic. It is very dangerous because we will get false results when the volatility and flow relation is not a one-one function. As far as we know, the tests so far regarding the relation between volatility and flow (or changes of institutional ownership) do not differentiate positive and negative flow, or changes of ownership (see, for example, Sias, 1996). Thus, we will revise the previous models by differentiating positive and negative flow to investigate whether there exists an asymmetric relation between volatility and flow.

\subsubsection{Regressions of volatility on inflow and outflow}


To examine the impact of inflow and outflow on the market volatility respectively, we examine the following models:

$$
\begin{aligned}
& \operatorname{Ln}\left(\sigma_{\mathrm{High}, \mathrm{t}}\right)=\text { Flow }_{\mathrm{t}} * \mathrm{D} 1+\text { Flow }_{\mathrm{t}} * \mathrm{D} 2+\operatorname{Ln}\left(\sigma_{\mathrm{High}, \mathrm{t}-1}\right)+\operatorname{Ln}\left(\sigma_{\mathrm{High}, \mathrm{t}-2}\right)+\operatorname{Ln}\left(\sigma_{\mathrm{High}, \mathrm{t}-3}\right) \\
& \operatorname{Ln}\left(\sigma_{\mathrm{High}, \mathrm{t}}\right)=\text { Flow }_{\mathrm{t}} * \mathrm{D} 1+\text { Flow }_{\mathrm{t}} * \mathrm{D} 2+\mathrm{D} 3+\operatorname{Ln}\left(\sigma_{\mathrm{High}, \mathrm{t}-1}\right)+\operatorname{Ln}\left(\sigma_{\mathrm{High}, \mathrm{t}-2}\right)+\operatorname{Ln}\left(\sigma_{\mathrm{High}, \mathrm{t}-3}\right) \\
& \operatorname{Ln}\left(\sigma_{\text {High }, \mathrm{t}}\right)=\text { Flow }_{\mathrm{t}} * \mathrm{D} 1+\text { Flow }_{\mathrm{t}} * \mathrm{D} 2+\mathrm{D} 3+\mathrm{TV}_{\mathrm{t}}+\operatorname{Ln}\left(\sigma_{\mathrm{High}, \mathrm{t}-1}\right)+\operatorname{Ln}\left(\sigma_{\mathrm{High}, \mathrm{t}-2}\right)+\operatorname{Ln}\left(\sigma_{\mathrm{High}, \mathrm{t}-3}\right) \\
& \text { Where } \mathrm{D} 1=1 \text {, if flow } \mathrm{t} \geq 0 \text {, and } \mathrm{D} 1=0 \text { if } \text { flow }_{\mathrm{t}}<0 \text {; } \\
& \mathrm{D} 2=0 \text {, if flow } \mathrm{t} \geq 0 \text {, and D2 }=-1 \text { if flow } \mathrm{t}<0 \text {; } \\
& \text { D3 }=1 \text {, if } \text { return }_{t} \geq 0 \text { and D3 }=0 \text { if return }{ }_{t}<0 \text {. }
\end{aligned}
$$

$\sigma_{\text {High, } t}$ is the high-frequency volatility estimator on day $t$, flow ${ }_{t}$ is the aggregate net mutual fund flow on day $\mathrm{t}, \mathrm{TV}_{\mathrm{t}}$ refers to the trading volume (we use turnover as proxy) on day $\mathrm{t}$.

\section{Insert Table 5}

Table 5 presents the results of the revised models. We introduce two dummy variables to accomplish our differentiation between inflow and outflow. The first dummy variable is defined as 1 when aggregate net flow is positive and 0 when aggregate net flow is negative. The second dummy variable is defined as -1 when aggregate net flow is negative and 0 when aggregate net flow is positive. In Column 1, daily volatility is regressed on absolute value of inflow and outflow (using two dummy variables defined before) respectively after controlling for the persistence of volatility. In Column 2, we control for the impact of return by introducing another dummy variable, which is defined as 1 when the market return is positive and 0 when the market return is negative. We also include turnover rate in Column 3 as explanatory variable.

A very interesting finding is that there exist asymmetric concurrent relations between volatility and flow, depending on the direction of flow: fund inflow is negatively related to market volatility while fund outflow is positively related to market volatility. In other words, the larger is the aggregate cash flow into the mutual funds, the less volatile is the market. On the other hand, the larger is the aggregate 
cash flow out of the mutual funds, the more volatile is the market. We illustrate this asymmetry in Figure 4.

\section{Insert Figure 4}

The slopes of solid lines in Figure 4 roughly show the asymmetric relation between volatility and flow. Moreover, the slope of the dotted line that connects the midpoints of the two solid lines in the figure above suggests that a negative correlation is likely to be detected when volatility-flow relation is examined across a broad flow range. This is just the case-we detect significantly negative concurrent relations between volatility and flow in the previous sub-section. Thus, previous models that do not take into account the direction of flow seem to be misspecified.

\section{4. Robustness tests}

\section{4. 1. Tests of outliers}

Our sample covers about 430 U.S. equity mutual funds, including funds with the investment objectives varying from aggressive growth to precious metals. In particular, from Panel A. of Table 1, average flows of funds with the investment objectives of AG, GI, LG and SF are positive while average flows of funds including TR, UT, IN and PM are negative. Suppose, if particular funds have especially large inflow or outflow, the results previously reported in this paper would lose much of their appeal because it is these outliers rather than the whole sample that drive their significance.

To test this possibility, we construct a new variable, dispersion rate (DR), as follows:

$$
D R_{t}=\frac{M_{t}-N_{t}}{T_{t}}
$$

where $M_{t}$ refers to the number of funds whose flow on day $t$ is positive, $N_{t}$ is the number of funds whose flow on day $t$ is negative, and $T_{t}$ is the total number of funds on day $t$. Table 6 shows the summary statistics of DR. Among 735 observations of DR, 250 observations are positive with the mean of 0.119 and 485 observations are negative with the mean of -0.177 . Besides, the correlation between flow and DR variable across the whole time period is 0.63 . 


\section{Insert Table 6}

We perform similar tests on DR to examine whether any outliers induce this asymmetric volatility-flow relation. The models are specified as follows:

$$
\begin{aligned}
& \operatorname{Ln}\left(\sigma_{\text {High, }}\right)=\mathrm{DR}_{\mathrm{t}} * \mathrm{D} 1+\mathrm{DR}_{\mathrm{t}} * \mathrm{D} 2+\operatorname{Ln}\left(\sigma_{\mathrm{High}, \mathrm{t}-1}\right)+\operatorname{Ln}\left(\sigma_{\mathrm{High}, \mathrm{t}-2}\right)+\operatorname{Ln}\left(\sigma_{\mathrm{High}, \mathrm{t}-3}\right) \\
& \operatorname{Ln}\left(\sigma_{\text {High, }}\right)=\mathrm{DR}_{\mathrm{t}} * \mathrm{D} 1+\mathrm{DR}_{\mathrm{t}} * \mathrm{D} 2+\mathrm{D} 3+\operatorname{Ln}\left(\sigma_{\mathrm{High}, \mathrm{t}-1}\right)+\operatorname{Ln}\left(\sigma_{\mathrm{High}, \mathrm{t}-2}\right)+\operatorname{Ln}\left(\sigma_{\mathrm{High}, \mathrm{t}-3}\right) \\
& \operatorname{Ln}\left(\sigma_{\text {High, }}\right)=\mathrm{DR}_{\mathrm{t}} * \mathrm{D} 1+\mathrm{DR}_{\mathrm{t}} * \mathrm{D} 2+\mathrm{D} 3+\mathrm{TV}_{\mathrm{t}}+\mathrm{Ln}\left(\sigma_{\mathrm{High}, \mathrm{t}-1}\right)+\operatorname{Ln}\left(\sigma_{\mathrm{High}, \mathrm{t}-2}\right)+\operatorname{Ln}\left(\sigma_{\mathrm{High}, \mathrm{t}-3}\right) \\
& \text { Where } \mathrm{D} 1=1 \text {, if } \mathrm{DR}_{t} \geq 0 \text {, and } \mathrm{D} 1=0 \text { if } \mathrm{DR}_{t}<0 \text {; } \\
& \mathrm{D} 2=0 \text {, if } \mathrm{DR}_{\mathrm{t}} \geq 0 \text {, and } \mathrm{D} 2=-1 \text { if } \mathrm{DR}_{\mathrm{t}}<0 \text {; } \\
& \text { D3 }=1 \text {, if } \text { return }_{t} \geq 0 \text { and D3=0 if return }{ }_{t}<0 \text {. }
\end{aligned}
$$

$\sigma_{\text {High, } t}$ is the high-frequency volatility estimator on day $t, \mathrm{DR}_{\mathrm{t}}$ is the diversion rate as we defined before on day $\mathrm{t}, \mathrm{TV}_{\mathrm{t}}$ refers to the trading volume (we use turnover as proxy) on day t. The subscripts indicate the day lagged.

\section{Insert Table 7}

The results are shown in table 7. In Column 1, we regress natural logarithm of volatility on positive DR and absolute value of negative value respectively after controlling for the persistence of volatility. In Column 2, we also control for the impact of return by using a dummy variable. In addition, turnover rate is included in Column 3 as a controlling variable.

The results also show an asymmetric pattern. That is, there is a negative relation between concurrent volatility and positive dispersion rate and there is a positive relation between concurrent volatility and absolute value of negative dispersion rate. The implication of the results is there do not exist outliers in mutual funds that drive the results.

\section{4. 2. Alternative volatility estimators}

As mentioned before, the regressions that use a market volatility estimate as a dependent variable are subject to an errors-in-the-variables problem. To prevent our results from being sensitive to particular volatility estimator used, we repeat our tests 
using two alternative volatility estimators discussed before: high-low volatility and implied volatility index. For brevity, we only show the results for the most comprehensive models. The results appear in Table 8 .

\section{Insert Table 8}

From Table 8 , the results using two alternative volatility estimators are very similar to the results presented before. Nevertheless, the results are a little weaker compared with those using high-frequency volatility. Thus, we conclude that our results of asymmetric relation between volatility and flow are not driven due to particular volatility estimator used.

\section{4. 3. Sub-time periods tests}

We also divide our sample period into two sub-time periods: one is from Feb. 1998 to June 1999, which is consistent with the time period in Edelen and Warner (2001); the other begins at July 1999 and ends with Dec. 2000. Then we replicate all the tests for the two sub-time periods. Also for brevity, we only show the most comprehensive models using high-frequency volatility. Table 9 presents the results.

\section{Insert Table 9}

The results are on a large part consistent with our previous results. For example, we get the inflow estimates of -33.4 with the $t$ statistic of -2.94 and -38.1 with the $t$ statistic of -2.83 for two sub-time periods. At the same time, the outflow estimates during two sub-time periods are 25.5 with the $t$ statistic of 1.93 and 63.1 with the $t$ statistic of 2.33 respectively.

\section{4. 4. Other tests}

We also perform two additional tests as we mentioned before. First, we would include global equity (GE) and balanced funds (BL) in our sample to check whether the results are sensitive to them. Second, we would repeat the analysis, excluding the December data from our sample to check the dividend effect since most dividends are distributed in December. However, meaningful changes do not occur in these tests, but to save space, the results are not reported. 


\section{Discussion: Why Asymmetric Relation?}

\subsection{Who are decision makers? Two hypotheses.}

The asymmetric relation between volatility and flow suggests two, though not mutually exclusive, stories. On the one hand, individual investors may play an important part in the market by buying (redeeming) mutual fund shares when market is up (down). On the other hand, the proactive trading strategies (e.g., herding) of mutual fund money managers may also drive the market. Then a specific question arises: who are decision makers? In other words, who are responsible for the concurrent asymmetric volatility-flow relation, individual investors or mutual fund managers?

It is well known that mutual funds are required by law to redeem shares on a daily basis, thus making mutual fund shares a very liquid investment. This liquidity service, as pointed out in Edelen (1999), forces mutual fund to engage in a substantial amount of uninformed, liquidity-motivated trading, and this liquidity-motivated trading makes up a material fraction of the fund's overall trading activity. Then the question is whether this kind of liquidity-motivated trading is sufficient to deliver a meaningful movement in stock market volatility. Harris and Raviv (1993) and Shalen (1993) propose the dispersion of beliefs models, which show that a greater dispersion of beliefs, that is, a wider dispersion of expectations in the current and preceding rounds of trade, will create excess price variability relative to the equilibrium value. Especially, as Shalen (1993) has pointed out, uninformed (or less-informed) investors have difficulty in interpreting the noisy signals of price change, that is, they cannot differentiate the short-term random liquidity demand from the overall fundamental changes in supply and demand. This could result in a general discrepancy about the true price embodied in the revealed information. Thus this kind of wider dispersion of beliefs would make uninformed investors react to all changes in prices as if they truly reflect the information. Moreover, uninformed investors tend to revise their beliefs more frequently, thus resulting in slower disappearance of price fluctuations from their trading than those from their informed counterparts after the new public information. In these ways, uninformed investors would more likely overreact to fundamental price movements, which would lead to increased price volatility. 
Therefore, as mutual fund investors are uninformed or relatively uninformed (Warther, 1995), they possess no information or receive information on a delayed or secondhand basis, if they receive information at all, to the extent that mutual funds facilitate their entry into the market, and to the extend flow should proxy for the liquiditymotivated trading, mutual fund flow would inevitably induce greater price volatility.

However, this seems to tell only part of the stories. As we discussed before, the herding and positive-feedback trading strategies of mutual fund managers would exert significant influence on the market. Nevertheless, herding and positive-feedback trading does not necessarily destabilize or stabilize the market. For example, herding would destabilize the market when mutual fund managers ignore their own information about fundamentals and mimic the trading of others. Yet, herding might stabilize the market by speeding up the adjustment of prices to new fundamentals and making the market more efficient when funds react to the same fundamental information in a timely manner. We will show later that our findings will unite these two stories in a consistent framework.

\subsection{Information effect}

Chan and Lakonishok (1993) discuss the differences in the information content of institutional trades. They argue that "Since an institutional investor typically does not hold the market portfolio, the choice of a particular issue to sell, out of the limited alternatives in a portfolio, does not necessarily convey negative information. Rather, the stocks that are sold may already have met the portfolio's objectives, or there may be other mechanical rules, unrelated to expectations about future performance, for reducing a position. As a result, there are many liquidity-motivated reasons to dispose of a stock. In contrast, the choice of one specific issue to buy, out of the numerous possibilities on the market, is likely to convey favorable firm-specific news." Implied in this argument is the suggestion that buy orders of institutions convey more information than sell orders. In addition, Keim and Madhavan (1995) provide another channel through which the information content of buys is greater than sales: institutional traders can choose among various potential assets; however, their sales are limited to the assets they already own due to the short sales restriction. Keim and Madhavan (1997) also show that trading costs for buy-initiated trades exceed sellerinitiated trades and their findings are consistent with the differences of information 
content of buys and sales. Saar (2001) develops a model which shows that the trading strategy of mutual fund managers creates a difference between the information content of buys and sells. He proposes a "prototypical" mutual fund which describes the behavior and constraints of mutual funds. Specifically, he points out that the asymmetry is mainly driven by two factors: the first is the ability of portfolio managers to gather, analyze and optimally use the private information; the second is a set of trading constraints (e.g., restriction on the use of leverage and short sales) that portfolio managers face.

\subsection{Explanation: asymmetric relation}

Our findings of asymmetric concurrent volatility-flow relation are consistent with the differences of information content of mutual funds' buying and selling behavior discussed above. When the market is up, individual investors tend to buy mutual fund shares. Thus, large sums of cash flow into mutual funds and mutual fund managers will invest the money in a diversified portfolio. As pointed out by Saar (2001), mutual funds will devote substantial resources to gathering and analyzing private information and make investment decisions based on predictions and recommendations of their research departments. Under such circumstances, mutual funds might appear to herd if they all react to the same fundamental information. Thus, their trading or herding behaviors tend to stabilize the market by speeding up the adjustment of the prices to new fundamentals. If this is the case, we would expect negative relation between market volatility and aggregate mutual fund flow. That is just what we have found: more fund inflow is associated with less volatile market.

By contrast, during down market periods, individual investors tend to redeem mutual fund shares and large sums of money exit the mutual funds. Besides, mutual funds are subject to a set of constraints (Saar, 2001). For example, use of leverage is restricted in mutual fund charters; short sales are also forbidden. Hence, fund managers are forced to sell stocks from their portfolios to satisfy the liquidity requirement of individual investors more often than are forced to buy stocks. Moreover, fund managers may tend to over-react to market information or sell stocks in a panic when market is down. Thus, fund managers are less rational and their trading or herding on selling stocks contains less information than their trading or herding on buying stocks. As we discussed before, such herding will drive the prices 
away from the assets' fundamental values and destabilize the market. This is also consistent with our findings: the more is the aggregate mutual fund outflow, the more volatile is the market.

Taken together, we link the impact of individual investors and mutual fund managers in a unified framework and provide a potential explanation for our findings. A potential testing of our results is to investigate the impact of herding on buys or sales on the market respectively. However, this is beyond the availability of our data and thus the scope of this paper. Future tests on this issue will help shed more light on our asymmetric results.

\section{Conclusion}

In this paper, we use daily data to directly investigate the concurrent volatility-flow relation. Our high frequency data enable us to conduct rigorous tests which offer new evidence. Our studies are expected to shed light on the impact of institutional trading on the market and be of importance to investors, practitioners, academicians and regulators.

Our initial evidence suggests a significantly negative contemporaneous relation between volatility and aggregate net mutual fund flow across the whole flow range. However, additional insight on this issue is gained by differentiating the data between inflow and outflow. An important finding emerges after we take into account the direction of aggregate net flow: there is a marked asymmetry between the impact of inflow and outflow on the market. Increases in aggregate net inflow are accompanied by less volatile market; however, increases in aggregate net outflow are associated with more volatile market.

We discuss the potential explanations for our findings of asymmetric concurrent volatility-flow relation and suggest the joint roles played by individual investors and mutual fund managers in the market. Our results are also consistent with the differences of information content of mutual funds' buys and sales. 


\section{Reference:}

Andersen, T.G., Bollerslev, T., Diebold, F.X. and Ebens, H., 2001. "The distribution of realized stock return volatility." Journal of Financial Economics 61, 43-76

Andersen, T.G., Bollerslev, T., Diebold, F.X. and Labys, P., 2001. "The distribution of realized exchange rate volatility." Journal of the American Statistical Association $96,42-55$

Arbel, A., Carvell, S. and Strebel, P., 1983. "Giraffes, institutions and neglected firms.” Financial Analysts Journal 39, 55-63

Badrinath, S.G., Gay, G.D. and Kale, 1989. "Patterns of institutional investment, prudence, and the managerial safety-net hypothesis." Journal of risk and insurance 55, 605-629

Bikhchandani, S., Hirshleifer, D. and Welch, I., 1992. "A theory of fads, fashion, custom, and cultural change as informational cascades." Journal of Political Economy $100,992-1026$

Brennan, M.J., 1995. "The individual investor." Journal of Financial Research 18, 5974

Busse, J.A., 1999. "Volatility timing in mutual funds: evidence from daily returns." The Review of Financial Studies 12, 1009-1041

Campbell, J.Y., 1987. "Stock returns and the term structure." Journal of Financial Economics 18, 373-399

Campbell, R., Koedijk, K. and Kofman, P., 2002. "Increased correlation in bear markets." Financial Analysts Journal 58, 87-94 
Chalmers, J.M.R., Edelen, R.M. and Kadlec G.B., 2000. "The wildcard option in transacting mutual-fund shares." Working paper, University of Pennsylvania

Chan, L. and Lakonishok, J., 1993. "Institutional trades and intraday stock price behavior.” Journal of Financial Economics 33, 173-200

Chan, L. and Lakonishok, J., 1995. "The behavior of stock prices around institutional trades." Journal of Finance 50, 1147-1174

Chan, L. and Lakonishok, J., 1997. "Institutional equity trading costs: NYSE versus NASDAQ.” Journal of Finance 52, 713-735

Chan, L., Jegadeesh, N. and Lakonishok, J., 1996. "Momentum strategies.” Journal of Finance 51, 1681-1713

Chopra, N., Lakonishok, J. and Ritter, J., 1992. "Measuring abnormal performance-Do stocks overreact?" Journal of Financial Economics 49, 235-268

DeLong, J.B., Shleifer, A., Summers, L.H. and Waldmann, R.J., 1990a. "Noise trader risk in financial markets.” Journal of Political Economy 98, 703-739

DeLong, J.B., Shleifer, A., Summers, L.H. and Waldmann, R.J., 1990b. "Positive feedback investment strategies and destabilizing rational speculation." Journal of Finance 45, 379-395

DeLong, J.B., Shleifer, A., Summers, L.H. and Waldmann, R.J., 1991. "The survival of noise traders in financial markets." Journal of Business 64, 1-19

Dreman, D., 1979. "Contrarian investment strategy: the psychology of stock market success." (Random House, New York).

Edelen, R.M., 1999. "Investor flows and the assessed performance of open-end mutual funds." Journal of Financial Economics 53, 439-466 
Edelen, R.M. and Warner, J.B., 2001. “Aggregate price effects of institutional trading: a study of mutual fund flow and market returns." Journal of Financial Economics 59, $195-220$

French, K.R., Schwert, G.W. and Stambaugh, 1987. "Expected stock returns and volatility." Journal of Financial Economics 19, 3-30

Glosten, L.R., Jagannathan, R. and Runkle, D.E., 1993. "On the relation between the expected value and the volatility of the nominal excess return on stocks." Journal of Finance 48, 1779-1801

Goetzmann, W.N., Ivkovic, Z. and Rouwenhorst, K.G., 2000. "Day trading international mutual funds: evidence and policy solutions." Working paper, Yale University.

Gompers, P. and Metrick, A., 2001. "Institutional investors and equity prices." The Quarterly Journal of Economics 116, 229-259

Greene, J.T., 2000. "The dilution impact of daily fund flows on open-end mutual funds.” Working paper, Georgia State University.

Harris, L., 1984. "Transactions data tests of the mixture of distributions hypothesis." Working paper, Univ. of Southern CA.

Harris, L., 1986. "Cross-security tests of the mixture of distributions hypothesis." Journal of Financial and Quantitative Analysis 21, 39-46

Harris, M. and Artur, R., 1993. "Differences of opinion make a horse race." Review of Financial Studies 6, 473-506

Haugen, R.A., Talmor, E. and Torous, W.N., 1991. "The effect of volatility changes on the level of stock prices and subsequent expected returns." Journal of finance 46, 985-1007 
Hirshleifer, D., Subrahmanyam, A. and Titman, S., 1994. "Security analysis and trading patterns when some investors receive information before others." Journal of Finance 49, 1665-1698

Jegadeesh, N. and Titman, S., 1993. "Returns to buying winners and selling losers: implications for stock market efficiency." Journal of Finance 48, 65-91

Jones, C. and Lipson, M., 1999. "Execution costs of institutional equity orders." Journal of Financial Intermediation 8, 123-140

Karpoff, J.M., 1987. "The relation between price changes and trading volume: a survey." Journal of Financial and Quantitative Analysis 22, 109-126

Keim, D. and Madhavan, A., 1995. "Anatomy of the trading process: empirical evidence on the behavior of institutional trades" Journal of Financial Economics 37, 371-398

Keim, D. and Madhavan, A., 1997. "Transactions costs and investment style: an interexchange analysis of institutional equity trades." Journal of Financial Economics 46, 103-131

Kothare, M. and Laux, P.A., 1995. "Trading costs and the trading systems for Nasdaq stocks." Financial Analysts Journal 51, 42-53

Lakonishok, J., Shleifer, A. and Vishny, R.W., 1992. "The impact of institutional trading on stock prices." Journal of Financial Economics 32, 23-44

Lakonishok, J., Shleifer, A. and Vishny, R.W., 1994. "Contrarian investment, extrapolation, and risk." Journal of Finance 49, 1541-1578

Lockwood, L.J. and Linn, S.C., 1990. "An examination of stock market return volatility during overnight and intraday periods, 1964-1989.” Journal of Finance 45, $591-601$ 
Xu Yexiao. and Malkiel B.G, 2002. "Investigating the behavior of idiosyncratic volatility." Forthcoming in Journal of Business

Morgan, I.G., 1976. "Stock prices and heteroskedasticity." Journal of Business 49, 496-508

Nofsinger, J.R. and Sias, R.W., 1999. "Herding and feedback trading by institutional and individual investors.” Journal of Finance 54, 2263-2295

Parkinson, M., 1980. "The extreme value method for estimating the variance of the rate return." Journal of Business 53, 61-66

Reilly, F.K., 1979. "How institutional trading reduces market volatility." Journal of Portfolio Management 5, 11-17

Richardson, G., Sefcik, S.E. and Thompson, R., 1986. "A test of dividend irrelevance using volume reaction to a change in dividend policy." Journal of Financial Economics 17, 313-333

Rogalski, R.J., 1978. "The dependence of prices and volume." The Review of Economics and Statistics 36, 268-274

Saar, G., 2001. "Price impact asymmetry of block trades: an institutional trading explanation." Review of Financial Studies 14, 1153-1181

Scharfstein, D.S. and Stein, J.C., 1990. "Herd behavior and investment." American Economic Review 80, 465-479

Schwert, G.W., 1989. "Why does stock market volatility change over time?" Journal of Finance 44, 1115-1153

Shalen, C.T., 1993. "Volume, volatility, and the dispersion of beliefs." Review of Financial Studies 6, 405-434 
Sias, R.W. and Starks, L.T., 1997. "Return autocorrelation and institutional investors." Journal of Financial Economics 46, 103-131

Sias, R.W., 1996. "Volatility and the institutional investor." Financial analysts journal $52,13-20$

Warther, V., 1998. "Has the rise of mutual funds increased market instability?" Brookings-Wharton Papers on Financial Services, 239-262

Warther, V., 1995. "Aggregate mutual fund flows and security returns.” Journal of Financial Economics 39, 209-235

Wermers, R., 1999. "Mutual fund herding and the impact on stock prices." Journal of Finance 54, 581-622

Whitelaw, R.F., 1994. "Time variations and covariations in the expectation and volatility of stock market returns.” Journal of Finance 49, 515-541

Zweig, M., 1973. "An investor expectations stock price predictive model using closed-end fund premiums." Journal of Finance 28, 67-78 
Table 1

Summary statistics for daily mutual fund flow

Our data on daily flow (new subscriptions less redemptions), NAV and total net assets (TNA) come from Trim Tabs (TT) financial services of Santa Rosa, California. We match the whole sample of about 850 mutual funds in TT with those in CRSP survivor-bias free US mutual fund database and classify the mutual funds by the investment objectives defined by Investment Company Institute (ICI). Included in our sample of all U.S. equity funds are funds from aggressive growth (AG) to precious metals (PM). We apply two filters detailed in the main text, the absolute-value filter and the Reversal filters, to the TNA and NAV series and aggregate the two series. Flow is defined as the one-day percentage change in aggregate TNA, less the one-day percentage change in the aggregate NAV. Distributions are not accounted for in these data.

Time period: 2/3/98 - 12/29/00 (735 observations)

Sample: 411 U.S. Equity funds

Panel A. Univariate statistics and autocorrelations of fund flow

\begin{tabular}{|c|c|c|c|c|c|c|c|}
\hline \multirow{2}{*}{$\begin{array}{c}\text { Fund } \\
\text { investment } \\
\text { objective }\end{array}$} & \multirow{2}{*}{$\begin{array}{l}\text { Mean } \\
\text { (b.p.) }\end{array}$} & \multirow{2}{*}{$\begin{array}{c}\text { Median } \\
\text { (b.p.) }\end{array}$} & \multirow{2}{*}{$\begin{array}{l}\text { Std. } \\
\text { dev. } \\
\text { (b.p.) }\end{array}$} & \multirow{2}{*}{$\begin{array}{l}\text { Std.err } \\
\text { of } \\
\text { mean } \\
\text { (b.p.) }\end{array}$} & \multicolumn{3}{|c|}{ Autocorrelations } \\
\hline & & & & & Lag1 & Lag2 & Lag5 \\
\hline $\begin{array}{l}\text { Aggressive } \\
\text { growth (AG) }\end{array}$ & 4.54 & 3.54 & 25.6 & 0.95 & $-0.023 *$ & $-0.144^{*}$ & 0.094 \\
\hline $\begin{array}{l}\text { Growth and } \\
\text { income (GI) }\end{array}$ & 1.33 & 1.11 & 8.9 & 0.33 & $-0.193 *$ & 0.051 & $0.129 *$ \\
\hline $\begin{array}{l}\text { Long-term } \\
\text { growth (LG) }\end{array}$ & 3.63 & 2.57 & 23.3 & 0.86 & $-0.065^{*}$ & $-0.310 *$ & 0.003 \\
\hline $\begin{array}{l}\text { Sector funds } \\
\text { (SF) }\end{array}$ & 3.44 & 1.33 & 40.0 & 1.48 & $-0.223^{*}$ & $-0.075^{*}$ & -0.012 \\
\hline $\begin{array}{l}\text { Total return } \\
\text { (TR) }\end{array}$ & -4.44 & -4.35 & 18.2 & 0.67 & $-0.076^{*}$ & 0.031 & $0.122 *$ \\
\hline $\begin{array}{l}\text { Utility funds } \\
\text { (UT) }\end{array}$ & -1.91 & -2.97 & 38.0 & 1.41 & $-0.361 *$ & $0.009 *$ & 0.041 \\
\hline Income (IN) & -1.68 & -2.18 & 13.0 & 0.48 & $-0.076^{*}$ & 0.071 & $0.140 *$ \\
\hline $\begin{array}{l}\text { Precious } \\
\text { metals (PM) }\end{array}$ & -4.77 & -21.3 & 198.0 & 7.33 & $-0.147^{*}$ & $-0.237^{*}$ & -0.034 \\
\hline $\begin{array}{l}\text { All U.S. } \\
\text { equity funds }\end{array}$ & 2.94 & 1.63 & 15.6 & 0.58 & $-0.091 *$ & $-0.227 *$ & 0.060 \\
\hline
\end{tabular}

Panel B. Univariate statistics of aggregate net inflow and outflow

\begin{tabular}{cccccc} 
& Obs. & $\begin{array}{c}\text { Mean } \\
\text { (b.p.) }\end{array}$ & $\begin{array}{c}\text { Median } \\
\text { (b.p.) }\end{array}$ & $\begin{array}{c}\text { Std. dev. } \\
\text { (b.p.) }\end{array}$ & $\begin{array}{c}\text { Std. err of } \\
\text { mean (b.p.) }\end{array}$ \\
\cline { 2 - 6 } $\begin{array}{c}\text { Aggregate } \\
\text { net inflow }\end{array}$ & 416 & 11.83 & 9.00 & 12.8 & 0.63 \\
$\begin{array}{c}\text { Aggregate } \\
\text { net outflow }\end{array}$ & 319 & -8.62 & -6.69 & 10.5 & 0.59 \\
\hline
\end{tabular}

* Significant at 0.05 level, two-tailed test. 
Table 2

Summary statistics for alternative volatility estimators

Panel A shows the univariate statistics and autocorrelations of market high-frequency volatility $\left(\sigma_{H i g h}\right)$, high-low volatility $\left(\sigma_{H L}\right)$ and implied volatility $\left(\sigma_{V I X}\right)$ respectively.

$\sigma_{H i g h}$ is calculated from five-minute intraday returns of S\&P500 index using the estimator of ABDL (2001) and ABDE (2001). $\sigma_{H L}$ is calculated using the methods of Parkinson (1980). $\sigma_{V I X}$ is the implied volatility index based on the option of S\&P100 index quoted by the Chicago Board Exchange (CBOE). Panel B shows the correlations of these three volatility estimators. $t$-statistics are in parentheses.

Time period: 2/3/98 - 12/29/00 (735 observations)

Panel A. Univariate statistics and autocorrelations of volatility estimators

\begin{tabular}{lccccccc} 
& \multirow{2}{*}{$\begin{array}{c}\text { Mean } \\
(\%)\end{array}$} & $\begin{array}{c}\text { Median } \\
(\%)\end{array}$ & $\begin{array}{c}\text { Std.dev. } \\
(\%)\end{array}$ & $\begin{array}{c}\text { Std.err. } \\
\text { of mean }\end{array}$ & \multicolumn{2}{c}{ Autocorrelaitons } \\
\cline { 7 - 9 }$\sigma_{H i g h}$ & 16.3 & 15.2 & 6.8 & 0.25 & $0.624^{*}$ & $0.525^{*}$ & $0.480^{*}$ \\
$\sigma_{H L}$ & 15.6 & 14.0 & 8.2 & 0.30 & $0.368^{*}$ & $0.349^{*}$ & $0.286^{*}$ \\
$\sigma_{V I X}$ & 25.7 & 24.7 & 5.1 & 0.19 & $0.931^{*}$ & 0.877 & 0.832
\end{tabular}

Panel B. Correlations of volatility estimators

$\begin{array}{cccc} & \sigma_{H i g h} & \sigma_{H L} & \sigma_{V I X} \\ \sigma_{H i g h} & 1.0000 & & \\ & & & \\ \sigma_{H L} & \begin{array}{ccc}0.8059 * \\ (<0.0001)\end{array} & 1.0000 & \\ & 0.6999 * & 0.5909 * & 1.0000 \\ \sigma_{V I X} & (<0.0001) & (<0.0001) & \end{array}$

* Significant at 0.05 level, two-tailed test. 
Table 3

Contemporaneous relations between Returns and flow

In Panel A., daily flow is regressed on current and past observations of market returns of NYSE index $\left(\mathrm{R}_{\mathrm{t}}\right)$ and past observations of flow. In Panel B., daily returns of NYSE index are regressed on concurrent and lagged daily flow (Flow ${ }_{t}$ ) in column 4 , and on concurrent and lagged unexpected daily flow (Uflow ${ }_{t}$ ) and concurrent expected daily flow $\left(\right.$ Eflow $_{\mathrm{t}}$ ) in column 5 and 6. Expected daily flow is taken from Panel A, column 2. Unexpected flow is actual minus expected. The subscripts indicate the days lagged. $t$-statistics are in parentheses.

Time Period: 2/3/98-12/29/00(735 observations)

Sample: 411 U.S. Equity funds

Panel A. Flow dependence on returns and past flow

\begin{tabular}{|c|c|c|c|}
\hline \multirow{2}{*}{\multicolumn{4}{|c|}{ Coefficient on: }} \\
\hline & & & \\
\hline Intercept & $\begin{array}{l}0.00031 * \\
\quad(6.2)\end{array}$ & $\begin{array}{l}0.00031 * \\
\quad(8.2)\end{array}$ & $\begin{array}{l}0.00030 * \\
\quad(8.1)\end{array}$ \\
\hline $\mathrm{R}_{\mathrm{t}}$ & - & - & $\begin{array}{c}0.009^{*} \\
(2.01)\end{array}$ \\
\hline $\mathrm{R}_{\mathrm{t}-1}$ & $\begin{array}{c}0.068 * \\
(15.1)\end{array}$ & $\begin{array}{c}0.069 * \\
(15.6)\end{array}$ & $\begin{array}{c}0.066^{*} \\
(15.1)\end{array}$ \\
\hline $\mathrm{R}_{\mathrm{t}-2}$ & $\begin{array}{c}-0.036^{*} \\
(-5.9)\end{array}$ & $\begin{array}{c}-0.035^{*} \\
(-8.0)\end{array}$ & $\begin{array}{c}-0.038^{*} \\
(-8.5)\end{array}$ \\
\hline $\mathrm{R}_{\mathrm{t}-3}$ & $\begin{array}{l}-0.010 \\
(-1.87)\end{array}$ & $\begin{array}{l}-0.009 \\
(-1.67)\end{array}$ & - \\
\hline Flow $_{t-1}$ & - & $\begin{array}{c}-0.077^{*} \\
(-2.11)\end{array}$ & $\begin{array}{c}-0.077 * \\
(-2.12)\end{array}$ \\
\hline Flow $_{t-2}$ & - & $\begin{array}{l}-0.220 * \\
(-6.03)\end{array}$ & $\begin{array}{c}-0.225^{*} \\
(-6.18)\end{array}$ \\
\hline $\mathrm{R}^{2}$ & $28.5 \%$ & $32.3 \%$ & $33.3 \%$ \\
\hline
\end{tabular}

Panel B. Returns dependence on flow

\begin{tabular}{lclcc} 
Raw flow & 4 & Exp.-unexp. flow & 5 & 6 \\
\hline Coefficient on: & & Coefficient on: & & \\
Intercept & 0.00012 & Intercept & 0.00043 & 0.00013 \\
& $(0.25)$ & & $(0.01)$ & $(1.07)$ \\
Flow $_{\mathrm{t}}$ & $0.317^{*}$ & Uflow $_{\mathrm{t}}$ & $0.663^{*}$ & $0.629^{*}$ \\
& $(1.97)$ & & $(2.48)$ & $(2.01)$ \\
Flow $_{\mathrm{t}-1}$ & 0.021 & Uflow $_{\mathrm{t}-1}$ & 0.006 & - \\
& $(0.08)$ & & $(0.02)$ & - \\
Flow $_{\mathrm{t}-2}$ & -0.038 & Uflow $_{\mathrm{t}-2}$ & 0.273 & - \\
& $(-0.14)$ & & $(0.81)$ & - \\
Flow $_{\mathrm{t}-3}$ & -0.00002 & Uflow $_{\mathrm{t}-3}$ & -0.325 & - \\
& $(-0.00)$ & & $(-1.03)$ & - \\
Flow $_{\mathrm{t}-4}$ & -0.119 & Uflow $_{\mathrm{t}-4}$ & -0.089 & - \\
& $(-0.44)$ & & $(-0.28)$ & -
\end{tabular}




\begin{tabular}{lcccc} 
Flow $_{\mathrm{t}-5}$ & 0.115 & Uflow $_{\mathrm{t}-5}$ & 0.166 & - \\
& $(0.43)$ & & $(0.52)$ & - \\
& & & 0.483 & 0.459 \\
& & Eflow $_{\mathrm{t}}$ & $(0.98)$ & $(1.01)$ \\
$\mathrm{R}^{2}$ & & $2.3 \%$ & $1.9 \%$ \\
\hline
\end{tabular}

* Significant at 0.05 level, two-tailed test. 
Table 4 Regressions of high-frequency volatility on flow

Daily high-frequency volatility $\left(\ln \left(\sigma_{H i g h, t}\right)\right)$ is regressed on concurrent aggregate domestic equity fund flow in column 1 , after controlling for the persistence of the volatility. Column 2 controls for a dummy variable (dummy). Column 3 also controls for trading volume (TV) in addition to dummy. $\sigma_{H_{i g h}, t}$ is calculated from five-minute intraday returns of S\&P500 index using the estimator of ABDL (2001) and ABDE (2001). Dummy is defined as 1 when daily return of S\&P 500 is positive and 0 when daily return of S\&P 500 is negative. We use turnover rate as a proxy for trading volume. The subscripts indicate the days lagged. $t$-statistics are in parentheses.

Time period: 2/3/98 - 12/29/00 (735 observations)

Sample: 411 U.S. Equity funds

\begin{tabular}{|c|c|c|c|}
\hline & 1 & 2 & 3 \\
\hline \multicolumn{4}{|c|}{ Coefficient on: } \\
\hline Intercept & $\begin{array}{c}-0.389 * \\
(-6.56)\end{array}$ & $\begin{array}{c}-0.318^{*} \\
(-5.38)\end{array}$ & $\begin{array}{l}-1.049 * \\
(-11.68)\end{array}$ \\
\hline Flow $_{t}$ & $\begin{array}{c}-31.530 * \\
(-4.75)\end{array}$ & $\begin{array}{c}-29.228 * \\
(-4.50)\end{array}$ & $\begin{array}{c}-34.099 * \\
(-5.60)\end{array}$ \\
\hline Dummy & - & $\begin{array}{c}-0.120^{*} \\
(-6.00)\end{array}$ & $\begin{array}{c}-0.114^{*} \\
(-6.08)\end{array}$ \\
\hline $\mathrm{TV}_{\mathrm{t}}$ & - & - & $\begin{array}{c}88.165^{*} \\
(10.32)\end{array}$ \\
\hline $\operatorname{Ln}\left(\sigma_{H i g h, t-1}\right)$ & $\begin{array}{l}0.395 * \\
(10.94)\end{array}$ & $\begin{array}{l}0.404 * \\
(11.44)\end{array}$ & $\begin{array}{l}0.339 * \\
(10.09)\end{array}$ \\
\hline $\operatorname{Ln}\left(\sigma_{H i g h, t-2}\right)$ & $\begin{array}{l}0.236^{*} \\
(6.10)\end{array}$ & $\begin{array}{c}0.240 * \\
(6.33)\end{array}$ & $\begin{array}{c}0.036^{*} \\
(5.88)\end{array}$ \\
\hline $\operatorname{Ln}\left(\sigma_{H i g h, t-3}\right)$ & $\begin{array}{l}0.157 * \\
(4.36)\end{array}$ & $\begin{array}{c}0.150^{*} \\
(4.27)\end{array}$ & $\begin{array}{c}0.128 * \\
(3.89)\end{array}$ \\
\hline Adj $\mathrm{R}^{2}$ & $48.14 \%$ & $50.52 \%$ & $56.80 \%$ \\
\hline
\end{tabular}

* Significant at 0.05 level, two-tailed test. 
Table 5

Regressions of high-frequency volatility on aggregate net inflow and outflow

Daily high-frequency volatility $\left(\ln \left(\sigma_{H i g h, t}\right)\right)$ is regressed on concurrent aggregate net inflow and outflow (using two dummy variables, dummy 1 and dummy 2 ) in column 1 , after controlling for the persistence of the volatility. Column 2 controls for a dummy variable (dummy 3). Column 3 also controls for trading volume (TV) in addition to dummy 3. $\sigma_{H i g h, t}$ is calculated from five-minute intraday returns of S\&P500 index using the estimator of ABDL (2001) and ABDE (2001). Dummy 1 is defined as 1 when aggregate flow is positive and 0 when aggregate flow is negative. Dummy 2 is defined as -1 when aggregate flow is negative and 0 when aggregate flow is positive. Dummy 3 is defined as 1 when daily return of S\&P 500 is positive and 0 when daily return of S\&P 500 is negative. We use turnover rate as a proxy for trading volume. The subscripts indicate the days lagged. $t$-statistics are in parentheses.

Time period: 2/3/98 - 12/29/00 (735 observations)

Sample: 411 U.S. Equity funds

\begin{tabular}{|c|c|c|c|}
\hline & 1 & 2 & 3 \\
\hline \multicolumn{4}{|l|}{ Coefficient on: } \\
\hline Intercept & $\begin{array}{c}-0.389 * \\
(-6.45)\end{array}$ & $\begin{array}{c}-0.315^{*} \\
(-5.23)\end{array}$ & $\begin{array}{l}-1.296 * \\
(-13.83)\end{array}$ \\
\hline Flow $_{\mathrm{t}}{ }^{*}$ dummy 1 & $\begin{array}{c}-31.647^{*} \\
(-3.32)\end{array}$ & $\begin{array}{c}-31.215^{*} \\
(-3.35)\end{array}$ & $\begin{array}{c}-36.819 * \\
(-4.37)\end{array}$ \\
\hline Flow $_{t}{ }^{*}$ dummy 2 & $\begin{array}{c}31.335^{*} \\
(2.39)\end{array}$ & $\begin{array}{c}25.934 * \\
(2.02)\end{array}$ & $\begin{array}{c}28.035 * \\
(2.42)\end{array}$ \\
\hline Dummy3 & - & $\begin{array}{c}-0.121 * \\
(-6.01)\end{array}$ & $\begin{array}{c}-0.115^{*} \\
(-6.32)\end{array}$ \\
\hline $\mathrm{TV}_{\mathrm{t}}$ & - & - & $\begin{array}{r}110.740 * \\
(12.85)\end{array}$ \\
\hline $\operatorname{Ln}\left(\sigma_{H i g h, t-1}\right)$ & $\begin{array}{l}0.395 * \\
(10.93)\end{array}$ & $\begin{array}{l}0.404 * \\
(11.43)\end{array}$ & $\begin{array}{c}0.317^{*} \\
(9.70)\end{array}$ \\
\hline $\operatorname{Ln}\left(\sigma_{H i g h, t-2}\right)$ & $\begin{array}{c}0.236^{*} \\
(6.09)\end{array}$ & $\begin{array}{c}0.240 * \\
(6.33)\end{array}$ & $\begin{array}{c}0.200 * \\
(5.82)\end{array}$ \\
\hline $\operatorname{Ln}\left(\sigma_{H i g h, t-3}\right)$ & $\begin{array}{l}0.157^{*} \\
(4.36)\end{array}$ & $\begin{array}{l}0.150^{*} \\
(4.27)\end{array}$ & $\begin{array}{l}0.127 * \\
(3.99)\end{array}$ \\
\hline Adj $R^{2}$ & $48.07 \%$ & $50.46 \%$ & $59.61 \%$ \\
\hline
\end{tabular}

* Significant at 0.05 level, two-tailed test. 
Table 6

Dispersion rate statistics

Dispersion rate (DR) is calculated by dividing the difference between the number of funds with positive flow and the number of funds with negative flow on a day by the total number of funds on the same day. Statistics of positive DR $(D R>0)$ and negative $\mathrm{DR}(\mathrm{DR}<0)$ are also shown in this table.

Time period: 2/3/98 - 12/29/00 (735 observations)

\begin{tabular}{cccccc}
\hline & Obs. & Mean & Median & Std. dev. & $\begin{array}{c}\text { Std. err of } \\
\text { mean }\end{array}$ \\
\cline { 2 - 6 } DR & 735 & -0.077 & -0.091 & 0.173 & 0.0064 \\
Positive DR & 250 & 0.119 & 0.113 & 0.081 & 0.0051 \\
Negative DR & 485 & -0.177 & -0.165 & 0.110 & 0.0050 \\
\hline
\end{tabular}


Table 7

Regression of high-frequency volatility on dispersion rate

Daily high-frequency volatility $\left(\ln \left(\sigma_{H i g h, t}\right)\right)$ is regressed on positive and negative dispersion rate (DR) (using two dummy variables, dummy1 and dummy 2) in column 1 , after controlling for the persistence of the volatility. Column 2 controls for a dummy variable (dummy 3). Column 3 also controls for trading volume (TV) in addition to dummy 3. $\sigma_{H i g h, t}$ is calculated from five-minute intraday returns of S\&P500 index using the estimator of ABDL (2001) and ABDE (2001). DR is calculated by dividing the difference between the number of funds with positive flow and the number of funds with negative flow on a day by the total number of funds on the same day. Dummy 1 is defined as 1 when aggregate flow is positive and 0 when aggregate flow is negative. Dummy 2 is defined as -1 when aggregate flow is negative and 0 when aggregate flow is positive. Dummy 3 is defined as 1 when daily return of S\&P 500 is positive and 0 when daily return of S\&P 500 is negative. We use turnover rate as a proxy for trading volume. The subscripts indicate the days lagged. $t$ statistics are in parentheses.

Time period: 2/3/98 - 12/29/00 (735 observations)

\begin{tabular}{|c|c|c|c|}
\hline & 1 & 2 & 3 \\
\hline \multicolumn{4}{|l|}{ Coefficient on: } \\
\hline Intercept & $\begin{array}{c}-0.517 * \\
(-8.24)\end{array}$ & $\begin{array}{c}-0.443^{*} \\
(-7.13)\end{array}$ & $\begin{array}{l}-1.306^{*} \\
(-13.72)\end{array}$ \\
\hline $\mathrm{DR}_{\mathrm{t}}^{*}$ dummy 1 & $\begin{array}{c}-0.380 * \\
(-2.36)\end{array}$ & $\begin{array}{c}-0.362 * \\
(-2.31)\end{array}$ & $\begin{array}{c}-0.235^{\#} \\
(-1.63)\end{array}$ \\
\hline $\mathrm{DR}_{\mathrm{t}}^{*}$ dummy 2 & $\begin{array}{c}0.493 * \\
(4.99)\end{array}$ & $\begin{array}{c}0.500 * \\
(5.20)\end{array}$ & $\begin{array}{c}0.496^{*} \\
(5.44)\end{array}$ \\
\hline Dummy3 & - & $\begin{array}{c}-0.125^{*} \\
(-6.40)\end{array}$ & $\begin{array}{c}-0.121 * \\
(-6.72)\end{array}$ \\
\hline $\mathrm{TV}_{\mathrm{t}}$ & - & - & $\begin{array}{c}98.612 * \\
(11.35)\end{array}$ \\
\hline $\operatorname{Ln}\left(\sigma_{H i g h, t-1}\right)$ & $\begin{array}{c}0.357 * \\
(9.90)\end{array}$ & $\begin{array}{c}0.365^{*} \\
(10.39)\end{array}$ & $\begin{array}{r}0.298 * \\
(9.04)\end{array}$ \\
\hline $\operatorname{Ln}\left(\sigma_{H i g h, t-2}\right)$ & $\begin{array}{c}0.233 * \\
(6.20)\end{array}$ & $\begin{array}{c}0.238^{*} \\
(6.51)\end{array}$ & $\begin{array}{c}0.195^{*} \\
(5.73)\end{array}$ \\
\hline $\operatorname{Ln}\left(\sigma_{H i g h, t-3}\right)$ & $\begin{array}{c}0.159 * \\
(4.52)\end{array}$ & $\begin{array}{c}0.152 * \\
(4.43)\end{array}$ & $\begin{array}{c}0.134 * \\
(4.24)\end{array}$ \\
\hline $\operatorname{Adj} R^{2}$ & $50.42 \%$ & $53.01 \%$ & $60.08 \%$ \\
\hline
\end{tabular}

* Significant at 0.05 level, two-tailed test

\# Significant at 0.10 level, two-tailed test 
Table 8

Dependence of high-low volatility and implied volatility on aggregate net inflow and outflow

Controlling for the persistence of the volatility, trading volume (TV) and a dummy variable (dummy 3), daily high-low volatility $\left(\operatorname{Ln}\left(\sigma_{H L, t}\right)\right.$ ) and implied volatility $\left(\operatorname{Ln}\left(\sigma_{V I X, t}\right)\right)$ are regressed on concurrent aggregate net inflow and outflow (using two dummy variables, dummy1 and dummy 2) in column 1 and column 2 respectively. $\sigma_{V I X, t}$ is calculated using the methods of Parkinson (1980). $\sigma_{V I X, t}$ is the implied volatility index based on the option of S\&P100 index quoted by the Chicago Board Exchange (CBOE). Dummy 1 is defined as 1 when aggregate flow is positive and 0 when aggregate flow is negative. Dummy 2 is defined as -1 when aggregate flow is negative and 0 when aggregate flow is positive. Dummy 3 is defined as 1 when daily return of S\&P 500 is positive and 0 when daily return of S\&P 500 is negative. We use turnover rate as a proxy for trading volume. The subscripts indicate the days lagged.

Time period: 2/3/98 - 12/29/00 (735 observations)

Sample: 411 U.S. Equity funds

\begin{tabular}{|c|c|c|c|c|}
\hline & \multicolumn{2}{|c|}{1} & \multicolumn{2}{|c|}{2} \\
\hline & \multicolumn{2}{|c|}{$\operatorname{Ln}\left(\sigma_{H L, t}\right)$} & \multicolumn{2}{|c|}{$\operatorname{Ln}\left(\sigma_{V I X, t}\right)$} \\
\hline & Estimate & T-value & Estimate & T-value \\
\hline Intercept & $-1.535^{*}$ & -11.97 & $-0.034^{\#}$ & -1.67 \\
\hline Flow $_{t}{ }^{*}$ dummy 1 & $-39.671 *$ & -3.03 & $-4.835^{*}$ & -2.69 \\
\hline Flow $_{t}{ }^{*}$ dummy 2 & $48.481 *$ & 2.71 & $4.066^{\#}$ & 1.82 \\
\hline Dummy3 & $-0.160 *$ & -5.68 & $-0.085^{*}$ & -22.96 \\
\hline $\mathrm{TV}_{\mathrm{t}}$ & $114.305^{*}$ & 9.20 & $3.885^{*}$ & 2.34 \\
\hline $\operatorname{Ln}\left(\sigma_{t-1}\right)$ & $0.151 *$ & 4.43 & $0.950 *$ & 90.32 \\
\hline $\operatorname{Ln}\left(\sigma_{t-2}\right)$ & $0.237 *$ & 7.00 & - & - \\
\hline $\operatorname{Ln}\left(\sigma_{t-3}\right)$ & $0.133^{*}$ & 3.94 & - & - \\
\hline $\operatorname{Adj} R^{2}$ & \multicolumn{2}{|c|}{$34.70 \%$} & \multicolumn{2}{|c|}{$94.02 \%$} \\
\hline
\end{tabular}

* Significant at 0.05 level, two-tailed test.

" Significant at 0.10 level, two-tailed test. 
Table 9

Sub-period check of high-frequency volatility on aggregate net inflow and outflow

Controlling for the persistence of the volatility, trading volume (TV) and a dummy variable (dummy 3), daily high-frequency volatility $\left(\ln \left(\sigma_{H i g h, t}\right)\right)$ is regressed on concurrent aggregate net inflow and outflow (using two dummy variables, dummy1 and dummy 2)during two sub-time periods in column 1 and column 2. $\sigma_{H i g h, t}$ is calculated from five-minute intraday returns of S\&P500 index using the estimator of ABDL (2001) and ABDE (2001). Dummy 1 is defined as 1 when aggregate flow is positive and 0 when aggregate flow is negative. Dummy 2 is defined as -1 when aggregate flow is negative and 0 when aggregate flow is positive. Dummy 3 is defined as 1 when daily return of S\&P 500 is positive and 0 when daily return of S\&P 500 is negative. We use turnover rate as a proxy for trading volume. The subscripts indicate the days lagged. $t$-statistics are in parentheses.

Time period 1: 2/3/98 - 6/30/99 (355 observations)

Time period 2: 7/1/99 - 12/29/00 (380 observations)

Sample: 411 U.S. Equity funds

\begin{tabular}{|c|c|c|c|c|}
\hline & \multicolumn{2}{|c|}{1} & \multicolumn{2}{|c|}{2} \\
\hline & \multicolumn{2}{|c|}{ Time period 1} & \multicolumn{2}{|c|}{ Time period 2} \\
\hline & Estimate & T-value & Estimate & T-value \\
\hline Intercept & $-1.064 *$ & -7.80 & $-1.442 *$ & -10.56 \\
\hline Flow $_{t}^{*}$ dummy 1 & $-33.404 *$ & -2.94 & $-38.113 *$ & -2.83 \\
\hline Flow $_{t} *$ dummy 2 & $25.459^{\#}$ & 1.93 & $63.096 *$ & 2.33 \\
\hline Dummy3 & $-0.137 *$ & -5.13 & $-0.095^{*}$ & -3.69 \\
\hline $\mathrm{TV}_{\mathrm{t}}$ & $132.201 *$ & 7.12 & $107.138^{*}$ & 9.48 \\
\hline $\operatorname{Ln}\left(\sigma_{H i g h, t-1}\right)$ & $0.357 *$ & 7.42 & $0.300 *$ & 6.53 \\
\hline $\operatorname{Ln}\left(\sigma_{H i g h, t-2}\right)$ & $0.236^{*}$ & 4.54 & $0.166^{*}$ & 3.51 \\
\hline $\operatorname{Ln}\left(\sigma_{H i g h, t-3}\right)$ & $0.166^{*}$ & 3.47 & $0.086^{*}$ & 1.96 \\
\hline Adj $R^{2}$ & & & & \\
\hline
\end{tabular}

* Significant at 0.05 level, two-tailed test.

\# Significant at 0.10 level, two-tailed test. 


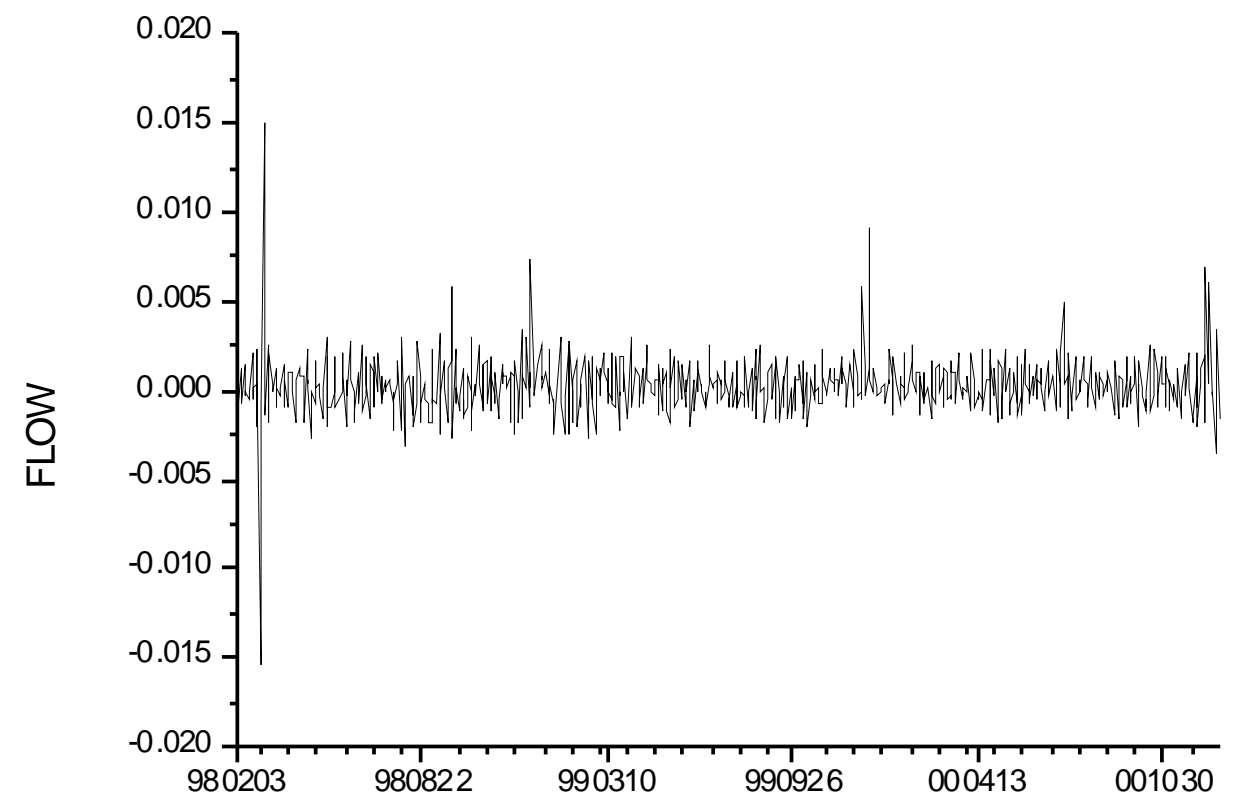

Fig. 1. Time series of daily aggregate U.S. equity mutual fund flow. The figure shows the time series of daily aggregate domestic equity mutual fund flow. Our data on flow (new subscriptions less redemptions) come from Trim Tabs (TT) financial services of Santa Rosa, California. Flow is defined as the one-day percentage change in aggregate TNA, less the one-day percentage change in the aggregate NAV. The sample covers the period from February 3, 1998 through December 29, 2000, for a total of 735 observations. 

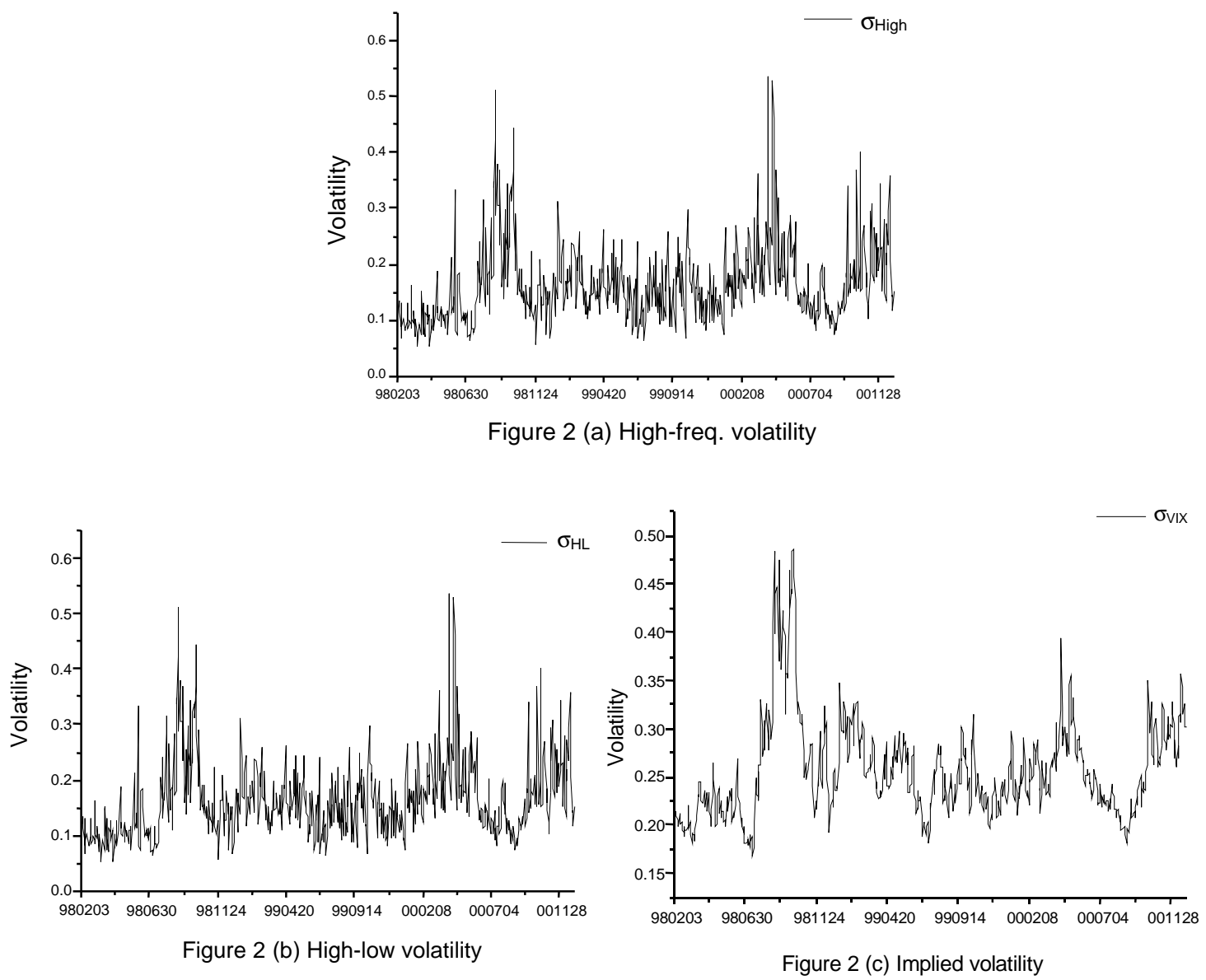

Fig. 2. Time series of different volatility estimators. The figure shows time series of three different market volatility estimators: high-frequency volatility $\left(\sigma_{H i g h}\right)$ in (a), high-low volatility $\left(\sigma_{H L}\right)$ in (b) and implied volatility $\left(\sigma_{V I X}\right)$ in (c). $\sigma_{H i g h}$ is calculated from five-minute intraday returns of S\&P500 index using the estimator of ABDL (2001) and ABDE (2001). $\sigma_{H L}$ is calculated using the methods of Parkinson (1980). $\sigma_{V I X}$ is the implied volatility index based on the option of S\&P100 index quoted by the Chicago Board Exchange (CBOE). The sample covers the period from February 3, 1998 through December 29, 2000, for a total of 735 observations. 


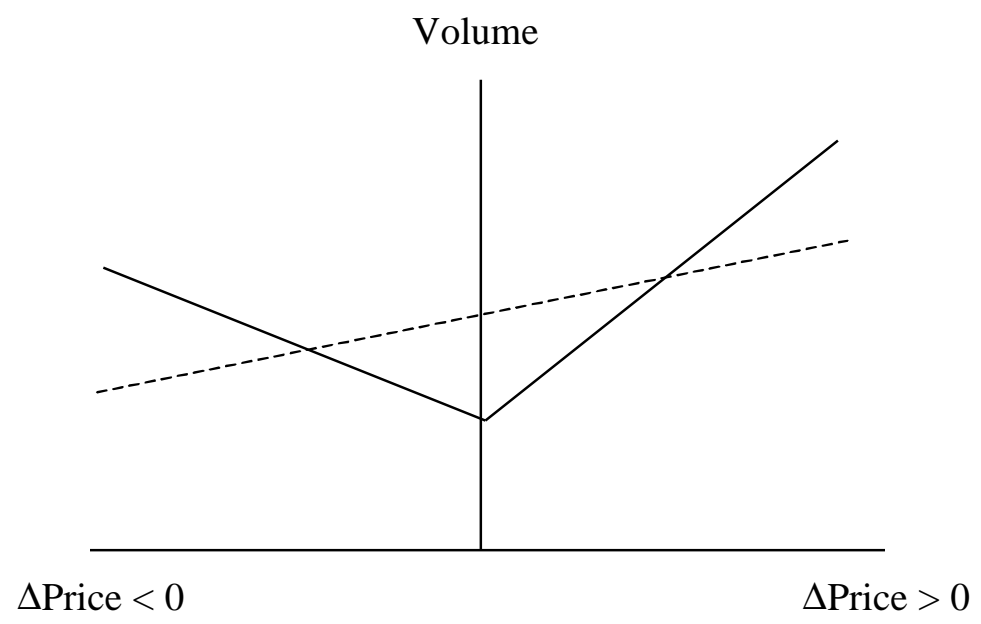

Fig. 3. Illustration of an asymmetric volume-price change relation (Karpoff, 1987). The figure illustrates the asymmetric concurrent volume-price change relation. The solid lines represent the asymmetric volume-price change relation depending on the direction of the price changes: volume is positively correlated with positive price changes and negatively correlated with negative price changes. The dotted line represents the positive correlation between volume and price changes per se.

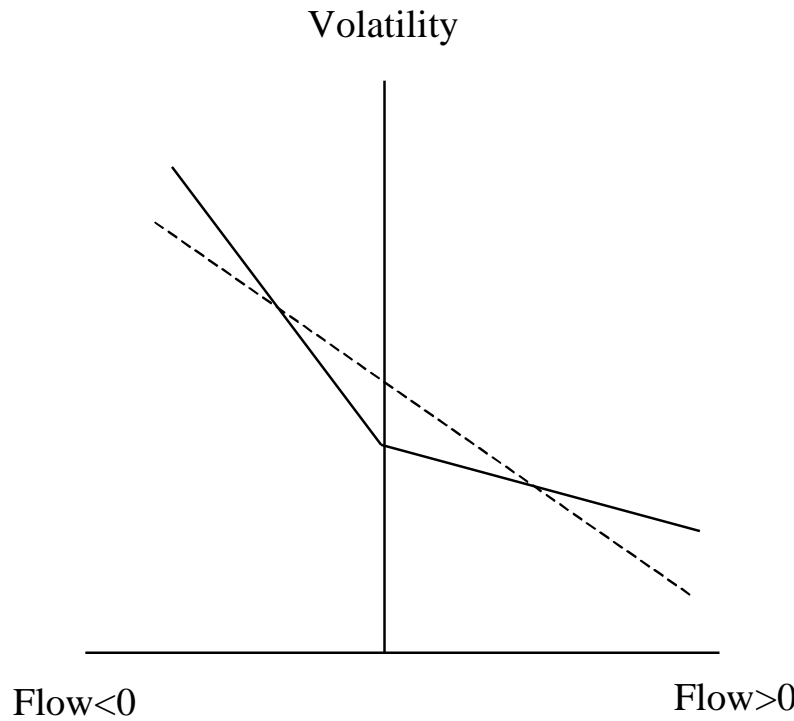

Fig. 4. Illustration of an asymmetric volatility-flow relation. The figure illustrates the asymmetric concurrent volatility-flow relation. The solid lines represent the asymmetric volatility-flow relation depending on the direction of flow: volatility is negatively correlated with inflow and positively correlated with outflow (ignore the sign). The dotted line represents the negative correlation between volatility and flow per se. 